\title{
Lack of correlation between the levels of soluble cytotoxic T-lymphocyte associated antigen-4 (CTLA-4) and the CT-60 genotypes
}

\author{
Sharad Purohit ${ }^{\dagger 1}$, Robert Podolsky ${ }^{\dagger 1}$, Christin Collins ${ }^{1}$, Weipeng Zheng ${ }^{1}$, \\ Desmond Schatz ${ }^{2}$, Andy Muir ${ }^{1}$, Diane Hopkins ${ }^{1}$, Yi-Hua Huang ${ }^{1}$ and Jin- \\ Xiong She*1
}

Address: ${ }^{1}$ Center for Biotechnology and Genomic Medicine, Medical College of Georgia, CA4095 Augusta, GA 30912 and ${ }^{2}$ Department of Pediatrics, University of Florida, Gainesville FL 32607, USA

Email: Sharad Purohit - spurohit@mail.mcg.edu; Robert Podolsky - rpodolsky@mail.mcg.edu; Christin Collins - ccollins@mail.mcg.edu; Weipeng Zheng -wzheng@mail.mcg.edu; Desmond Schatz - Schatda@peds.ufl.edu; Andy Muir - amuir@mail.mcg.edu; Diane Hopkins - dhopkins@mail.mcg.edu; Yi-Hua Huang - yhuang@mail.mcg.edu; Jin-Xiong She* - jshe@mail.mcg.edu

* Corresponding author †Equal contributors

Published: 31 October 2005

Journal of Autoimmune Diseases 2005, 2:8 doi:10.1 186/1740-2557-2-8

This article is available from: http://www.jautoimdis.com/content/2/l/8

(C) 2005 Purohit et al; licensee BioMed Central Ltd.

This is an Open Access article distributed under the terms of the Creative Commons Attribution License (http://creativecommons.org/licenses/by/2.0), which permits unrestricted use, distribution, and reproduction in any medium, provided the original work is properly cited.
Received: 16 August 2005

Accepted: 31 October 2005

\begin{abstract}
Background: Cytotoxic T lymphocyte-associated antigen-4 (CTLA-4) plays a critical role in downregulation of antigen-activated immune response and polymorphisms at the CTLA-4 gene have been shown to be associated with several autoimmune diseases including type-I diabetes (TID). The etiological mutation was mapped to the CT60-A/G single nucleotide polymorphism (SNP) that is believed to control the processing and production of soluble CTLA-4 (sCTLA-4).

Methods: We therefore determined sCTLA-4 protein levels in the sera from 82 TID patients and 19 autoantibody positive (AbP) subjects and I I 7 autoantibody negative (AbN) controls using ELISA. The CT-60 SNP was genotyped for these samples by using PCR and restriction enzyme digestion of a 268 bp DNA segment containing the SNP. Genotyping of CT-60 SNP was confirmed by dye terminating sequencing reaction.
\end{abstract}

Results: Higher levels of sCTLA-4 were observed in TID $(2.24 \mathrm{ng} / \mathrm{ml})$ and AbP (mean = $2.17 \mathrm{ng} /$ $\mathrm{ml}$ ) subjects compared to $\mathrm{AbN}$ controls (mean $=1.69 \mathrm{ng} / \mathrm{ml}$ ) with the differences between these subjects becoming significant with age $(p=0.02)$. However, we found no correlation between sCTLA-4 levels and the CTLA-4 CT-60 SNP genotypes.

Conclusion: Consistent with the higher serum sCTLA-4 levels observed in other autoimmune diseases, our results suggest that SCTLA-4 may be a risk factor for TID. However, our results do not support the conclusion that the CT-60 SNP controls the expression of sCTLA-4.

\section{Background}

Effective T cell activation requires a 'costimulation' signal that is mediated through CD28 interacting with B7 family members on antigen presenting cells (APC) [1]. The cytotoxic T lymphocyte associated antigen-4 (CTLA-4) was initially described as a $\mathrm{B} 7$ binding protein and a receptor 
expressed on the surface of activated T cells [2]. It belongs to the immunoglobulin gene superfamily and shares homology with CD28. CTLA-4 has been reported to be an important negative regulator of autoimmune diseases $[3,4]$. CTLA-4 blockade enhances $\mathrm{T}$ cell responses in vitro and in vivo [5,6], augments antitumor immunity [7] and exacerbates autoimmune diseases [8]. Several reports have indicated that CTLA-4 deficient mice show a severe lymphoproliferative disorder and autoimmune disease with early lethality $[9,10]$. Treatment with anti-CTLA-4 mAb of BDC2.5/NOD mice provoked a rapid onset of diabetes, indicating that a higher CTLA- 4 presence was required for suppression of autoimmune phenomenon in these mice $[11,12]$. Recently, a soluble form of CTLA-4 (sCTLA-4) was found to be expressed constitutively by unstimulated human T cells [13]. Circulating sCTLA-4 protein was found to be present in human serum and is shown to possess an inhibitory effect on mixed leucocyte response [14].

Several studies have demonstrated a genetic association between polymorphisms within or near the CTLA-4 gene and T1D [15-19] as well as other autoimmune diseases [20-24]. This susceptibility locus has been recognized as IDDM12. Our previous studies indicated that CTLA-4 was the only gene contained in the IDDM12 susceptibility interval, suggesting that CTLA-4 is indeed the IDDM12 gene [16]. In a recent report by Ueda et al [25] the susceptibility interval was further narrowed to a $6.1 \mathrm{~kb}$ region at the 3' UTR of the CTLA-4 gene and the CT60-A/G single nucleotide polymorphism (SNP) was suggested to be the etiological mutation. The susceptible CT60-G allele was reported to produce a lower amount of soluble CTLA-4 mRNA in the peripheral blood lymphocytes than the disease resistant CT60-A allele. These results suggested that sCTLA-4 may confer protective effect against T1D. If this effect is indeed true, one would predict lower sCTLA-4 in the serum in T1D patients compared to controls. However, the prediction is in direct conflict with the observations in other autoimmune diseases including autoimmune thyroid disease [26], systemic lupus erythematosus [27] and myasthenia gravis [28], in which the serum sCTLA-4 levels are increased in patients compared to controls. The measurement of serum sCTLA-4 protein in a larger sample set is vital in evaluating the potential role of SCTLA-4 in T1D, and to better understand the molecular and functional basis underlying the genetic association between the CTLA-4 gene and T1D.

\section{Methods}

\section{Patient sera}

The study population consists of 218 subjects from the South-eastern United States. All study subjects were genotyped for HLA-DQB1 and evaluated for three autoantibodies (IA-2A, GADA and IAA) using established methods $[29,30]$ Subjects used in this study are participants in the prospective assessment in newborns for diabetes autoimmunity (PANDA) program. Briefly, PANDA screens newborns from the general population as well as children with a first degree relative with T1D using HLA genotyping. Those subjects with high risk genes are monitored for the appearance of islet autoantibodies and clinical diabetes. Therefore, most of the autoantibody-negative (AbN) subjects also have high risk HLA genes and the AbN group is not randomly selected from the general population. The autoantibody-positive (AbP) subjects have been tested persistently positive for two or more islet autoantibodies. Based on our results from PANDA and previous studies, the AbP group has $70-80 \%$ of chance to progress to T1D [31] and indeed represent a very high risk group. Since autoantibody production is one of the hallmarks of autoimmunity, the AbP and T1D group can be combined to assess the impact of autoimmunity on the CTLA-4 levels. Appropriate institutional review boards approved the study design and informed consent was obtained from all subjects.

\section{Assay of sCTLA-4}

A sandwich ELISA assay as described by Oaks et al [26] was used to measure the serum sCTLA-4 levels in a total of 218 subjects, including 117 autoantibody-negative $(\mathrm{AbN}), 19$ autoantibody-positive (AbP) and 84 patients with T1D. The 96-well microtiter plates (Pierce Biotechnology, Rockford, IL) were coated with $1.0 \mathrm{ug} / \mathrm{ml}$ antiCTLA-4 monoclonal antibody (clone BNI3; Pharmingen, San Deigo, CA). After blocking, 100 ul of 1:10 diluted serum samples were added to each well and the plates were incubated for $2 \mathrm{hr}$ in a humid chamber at $37^{\circ} \mathrm{C}$ and then washed to remove unbound material. After washing, $100 \mathrm{ul}$ biotinylated anti-CTLA-4 mAb $(1.0 \mathrm{ug} / \mathrm{ml}$, clone AS-33, Antibody Solutions, Palo Alto, CA) was added and the reactions were incubated for another $1 \mathrm{hr}$ at $37^{\circ} \mathrm{C}$ in a humid chamber. Reactions were developed using streptavidin-peroxidase complex (Biorad, Hercules, CA) and 3,3',5,5'-tetramethy benzidine substrate (Sigma, St. Louis, $\mathrm{MO}$ ) for $10 \mathrm{~min}$ at room temperature, the reaction was terminated with $2 \mathrm{~N} \mathrm{H}_{2} \mathrm{SO}_{4}$ and optical density was read at $450 \mathrm{~nm}$ and $630 \mathrm{~nm}$. A standard curve was generated using a dilution series of commercially available CTLA-4Ig fusion protein $(0.125 \mathrm{ng} / \mathrm{ml}$ to $10 \mathrm{ng} / \mathrm{ml}$ Ancell, Bayport, $\mathrm{MN}$ ). This assay has a linear range between 0.5 and $10 \mathrm{ng} / \mathrm{ml}$ and the vast majority of the samples fall under this range. Each sample was analyzed in duplicate.

\section{Genotyping of 3' untranslated region of CTLA-4 gene}

A fragment of 268 bp encompassing the CTLA-4 C/T-60 single nucleotide polymorphism (SNP) in the 3 ' untranslated region was amplified using the forward primer 5'GCTTCATGAGTCAGCTTTGC3' and reverse primer 5'ATAGGACCACAGGT3'. The amplified PCR products were digested using the 10 units of HpyCH4IV (New Eng- 
Table I: Clinical and Demographic characteristics of subjects involved in the study with respect to number of individuals, age of diagnosis, duration of disease, genotype and antibody number.

\begin{tabular}{|c|c|c|c|}
\hline Variable & $\mathrm{AbN}$ & $A b P$ & TID \\
\hline Total number & 117 & 19 & 82 \\
\hline Age (years) & 15.1 & 14.5 & 15.8 \\
\hline $75 \%$ ile & 22.0 & 28.5 & 20.1 \\
\hline $90 \%$ ile & 37.0 & 37.0 & 36.0 \\
\hline Age range & $(0.8-48.6)$ & $(0.6-44.0)$ & $(0.9-43.7)$ \\
\hline Age of Diagnosis (years) & & & $8.8(0.8-4 \mid .2)$ \\
\hline Duration of TID (years) & & & $6.2(0-41.0)$ \\
\hline \multicolumn{4}{|l|}{ Age: $n$ (percent) } \\
\hline$<20$ years & $86(73.5 I)$ & $14(73.68)$ & $60(73.17)$ \\
\hline$>20$ years & 31 (26.49) & $5(26.32)$ & $22(26.83)$ \\
\hline \multicolumn{4}{|l|}{ Sex: n (percent) } \\
\hline Male & $53(45.30)$ & $9(47.37)$ & $50(60.97)$ \\
\hline Female & $64(54.70)$ & $10(52.63)$ & $32(39.03)$ \\
\hline \multicolumn{4}{|l|}{ Genotype: n (percent)* } \\
\hline $0201 / 0201$ & $8(6.84)$ & $0(0.00)$ & $13(15.85)$ \\
\hline $0302 / 0302$ & $12(10.26)$ & $4(21.05)$ & $6(7.32)$ \\
\hline $0201 / 0302$ & $31(26.50)$ & $5(26.32)$ & $38(46.34)$ \\
\hline $0201 / x$ & $21(17.95)$ & $3(15.79)$ & $10(12.20)$ \\
\hline $0302 / x$ & $23(19.66)$ & $4(21.05)$ & $\mathrm{II}(13.4 \mathrm{I})$ \\
\hline$x / x$ & $18(I 5.38)$ & $2(10.53)$ & $3(3.66)$ \\
\hline
\end{tabular}

Age, age of diagnosis and duration of disease is presented as means (range).

*Genotyping information was not available on one AbP, one TID and $4 \mathrm{AbN}$ individual(s).

Sex and genotype are presented as number of individuals of individuals (n). Values presented in parenthesis are percentage of total.

land Biolabs) and separated on 3\% agarose gels. The C-60 allele yielded two bands of 151 and $103 \mathrm{bp}$ and the T-60 allele yields a band of $268 \mathrm{bp}$. The genotyping technique for the C/T-60 SNP was further confirmed by DNA sequencing of a subset of samples using a 300XL DNA sequencer (ABI Sciex).

\section{Statistical Analysis}

Absorbance values obtained at $450 \mathrm{~nm}$ were normalized with the absorbance values at $630 \mathrm{~nm}$. sCTLA-4 levels were log-transformed prior to analysis. Two of the T1D subjects had very high sCTLA4 levels with serum CTLA4 levels were $>12 \mathrm{ng} / \mathrm{ml}$, or 3.5 standard deviations from the mean of $2.57 \mathrm{ng} / \mathrm{ml}$. Further, initial analyses involving analysis of variance (ANOVA) indicated these two subjects' values were outliers. As such, the data for these two subjects were removed from all subsequent analyses. We used linear-mixed model ANOVA (Proc Mixed procedure of SAS) in which plate was included as a random effect to examine differences in sCTLA4 levels. Initially we analyzed phenotypic group (AbN, AbP, and T1D) alone, but subsequently conducted separate analyses adding other factors. These analyses were as follows: (1) factorial ANOVA with phenotypic group and CTLA-4 genotype; (2) factorial ANOVA with phenotypic group and gender; (3) ANOVA with phenotypic group and age as a covariate, and the interaction between age and phenotypic group; (4) ANOVA with phenotypic group and duration of T1D as a covariate, and the interaction between duration of T1D and phenotypic group; and (5) factorial ANOVA with phenotypic group and HLA genotype.

\section{Results}

Clinical and demographic information is presented in Table 1. A majority of the subjects in the study were below the age of 20 years $(73 \%)$ in all three groups. The subjects were tested for IAA, GADA and IA-2A autoantibodies as well as HLA-DQB1 genotypes. HLA-DQB1 genotyping information was available for 96.58, 94.74 and 98.78 percent of patients from the $\mathrm{AbN}, \mathrm{AbP}$ and T1D groups, respectively. Eighty-eight percent of T1D subjects were diagnosed with T1D before the age of 20, with an average age of 8.8 (range $0.9-41.2$ ). Fifty-seven out of eighty-two T1'1D subjects have a T1D duration of five years and less.

We first compared the serum sCTLA-4 levels between the three phenotypic groups (i.e., AbN, AbP and T1D). The protein levels for T1D (mean $=2.24 \mathrm{ng} / \mathrm{ml}$, range $=0-$ $10.1 \mathrm{ng} / \mathrm{ml}$ ) and AbP (mean $=2.17 \mathrm{ng} / \mathrm{ml}$, range $=0.2-$ $7.7 \mathrm{ng} / \mathrm{ml}$ ) were slightly higher than that in $\mathrm{AbN}$ (mean = $1.69 \mathrm{ng} / \mathrm{ml}$, range $=0.0-11.5 \mathrm{ng} / \mathrm{ml}$ ) (Table 2 ), although these differences were not statistically significant.

The serum CTLA-4 levels were analyzed after stratification by phenotypic groups (T1D, $\mathrm{AbP}$ and $\mathrm{AbN}$ ) and the CTLA4 CT-60 SNP genotypes (A/A, A/G and G/G) (Table 2). A mixed model ANOVA using phenotypic group and CT-60 genotypes as factorial fixed effects revealed no differences in sCTLA-4 levels between CTLA-4 genotypes $(p=0.46)$ or genotype/phenotype interactions $(\mathrm{p}=0.82)$. A similar ANOVA using CT-60 genotypes alone as a fixed effect did not reveal any significant differences in sCTLA-4 levels between CTLA-4 genotypes $(\mathrm{p}=0.64)$.

We then analyzed the data after conditioning on genetic, phenotypic or demographic parameters. Neither gender showed differences in serum CTLA-4 levels between the three phenotypic groups (Table 2). The relationship between sCTLA-4 levels and age differed between the three phenotypic groups $(\mathrm{p}=0.022)$. The sCTLA-4 levels decreased with age in the controls ( $p=0.048$; Fig. 1 ). In contrast, sCTLA-4 levels increased with age in both the T1D and AbP groups (Fig. 1), although these relationships were not significant $(\mathrm{p}>0.1)$. This difference in the relationship with age will result in $\mathrm{AbN}$ controls having lower sCTLA-4 levels at later ages compared with both AbP and 
Table 2: sCTLA-4 levels in AbN, TID and AbP individuals. Values presented are mean and $95 \%$ confidence interval in ng/ml.

\begin{tabular}{|c|c|c|c|c|c|}
\hline Group & $\mathrm{AbN}$ & $\mathrm{AbP}$ & TID & TID/AbN & $\mathrm{AbP} / \mathrm{AbN}$ \\
\hline All subjects $(p=0.58)$ & $1.7(0.6-3.6)(n=117)$ & $2.2(0.5-5.5)(n=19)$ & $2.2(0.9-4.6)(n=82)$ & 1.3 & 1.3 \\
\hline \multicolumn{6}{|l|}{ CTLA-4 genotype } \\
\hline$A / A$ & $1.9(0.7-4.1)(n=12)$ & $2.5(n=1)$ & $1.9(0.8-4.9)(n=19)$ & 1.0 & 1.2 \\
\hline A/G & $1.5(0.5-4.0)(n=21)$ & $1.7(0.4-4.2)(n=7)$ & $1.9(0.7-3.8)(n=16)$ & 1.2 & I.I \\
\hline $\mathrm{G} / \mathrm{G}$ & $1.6(0.7-3.0)(n=49)$ & $2.5(0.9-5.4)(n=9)$ & $2.4(1.1-4.4)(n=26)$ & 1.3 & 1.3 \\
\hline Male $(p=0.53)$ & $1.7(0.9-2.8)(n=53)$ & $2.3(0.9-4.5)(n=9)$ & $2.3(\mathrm{I} .3-3.7)(\mathrm{n}=5 \mathrm{I})$ & 1.4 & 1.3 \\
\hline Female $(p=0.70)$ & $1.7(0.9-2.8)(n=64)$ & $2.1(0.8-4.2)(n=10)$ & $2.2(1.2-3.6)(n=31)$ & 1.3 & 1.2 \\
\hline DQBI*020I positive & $1.3(0.6-2.4)(n=60)$ & $1.8(0.6-4.0)(n=8)$ & $2.2(1.1-3.8)(n=62)$ & 1.7 & 1.4 \\
\hline DQBI*020I negative & $2.2(1.2-3.8)(n=53)$ & $3.3(1.4-6.8)(n=10)$ & $1.9(0.8-3.8)(\mathrm{n}=19)$ & 0.9 & 1.5 \\
\hline DQBI $* 0302$ positive & $1.6(0.8-2.9)(n=66)$ & $2.4(1.0-4.6)(n=13)$ & $2.3(1.2-3.9)(n=56)$ & $\mathrm{I} .4$ & 1.5 \\
\hline DQBI*0302 negative & $1.9(0.9-3.3)(n=47)$ & $2.6(0.9-5.9)(n=5)$ & $1.8(0.7-3.6)(n=25)$ & 1.0 & $\mathrm{I} .4$ \\
\hline
\end{tabular}

T1D subjects. Serum sCTLA-4 levels in T1D subjects did not show an association with duration of disease $(\mathrm{p}=0.4)$ nor with the age at disease onset $(\mathrm{p}=0.6$; data not shown).

The serum CTLA-4 levels were also analyzed after conditioning on the HLA-DQB1 genotypes by using phenotypic group, HLA-DQB1*201, and HLA-DQB1*302 as factorial fixed effects in a mixed model ANOVA. No differences were observed in sCTLA-4 levels between HLADQB ${ }^{*} 0302$ genotypes $(p=0.96)$, and the three phenotypic groups stratified by HLA-DQB1 genotype did not show any differences (Table $2, \mathrm{p}=0.51$ ). AbN subjects with the DQB1*201 allele tended to have lower sCTLA levels $(1.3 \mathrm{ng} / \mathrm{ml}$ vs $2.2 \mathrm{ng} / \mathrm{ml})$, although the difference was not significant, a similar trend was observed in AbP group $(1.8 \mathrm{ng} / \mathrm{ml}$ vs $3.3 \mathrm{ng} / \mathrm{ml})$. The T1D group subjects with and without DQB $1 * 201$ allele have a very similar levels of sCTLA-4 $(2.2 \mathrm{ng} / \mathrm{ml}$ vs $1.9 \mathrm{ng} / \mathrm{ml})$. The differences between the three phenotypic groups for subjects with the DQB1*201 allele were not significantly different from the differences observed for those without the DQB1 $* 201$ allele (Table 2; $\mathrm{p}=0.13$ ). The main effect of the $\mathrm{DQB}^{*} 0201$ allele in the factorial mixed-model ANOVA was marginally significant $(p=0.08)$ with serum CTLA-4 levels being lower in individuals with a DQB ${ }^{*} 0201$ allele $($ mean $=1.8 \mathrm{ng} / \mathrm{ml})$ than individuals without a DQB1 ${ }^{*} 0201$ allele $($ mean $=2.4 \mathrm{ng} / \mathrm{ml})$. We decided to redo this analysis by combining the AbP and T1D groups for three reasons: (1) sample sizes were small for some of the genotype/phenotype combinations; (2) subjects that are positive for multiple antibodies and with a high risk HLA genotype are much more likely to develop T1D in future; and (3) autoimmunity is the common denominator of the AbP and T1D groups. When the data were analyzed with these two phenotypic groups considered as a single group ( $\mathrm{AbP}+\mathrm{T} 1 \mathrm{D}$ vs. $\mathrm{AbN})$, the main effect of DQB $1 * 0201$ allele became significant $(p=0.02)$, with the remaining effects still not significant. T1D and AbP subjects did show a trend towards having larger
sCTLA-4 levels (mean $=2.2 \mathrm{ng} / \mathrm{ml}$ ) compared to the AbN subjects (mean $=1.3 \mathrm{ng} / \mathrm{ml}$ ) when only subjects with the DQB1*0201 were considered, however, the difference was not statistically significant $(\mathrm{p}=0.15)$.

\section{Discussion}

Type-1 diabetes is marked by the production of pancreatic islet $\beta$ cell-specific auotantibodies and destruction of the insulin-producing $\beta$ cells by autoreactive T cells. A role of CTLA- 4 in the pathogenesis in T1D and other autoimmune diseases has been well documented. In this study we provide some suggestive evidence that high risk autoantibody positive subjects and T1D patients both have increased levels of sCTLA-4 in serum compared to autoantibody-negative subjects. We observed that larger differences in sCTLA4 levels between T1D/AbP and AbN subjects occur in the older age group. Further, we observed a difference between $\mathrm{AbP} / \mathrm{T} 1 \mathrm{D}$ subjects and $\mathrm{AbN}$ subjects for those carrying the DQB $1{ }^{*} 0201$ allele.

As a negative regulator of $\mathrm{T}$ cell activation, blockade of CTLA- 4 by monoclonal anti-CTLA- 4 antibody provokes a rapid onset of diabetes in BDC2.5/NOD mouse model [11]. Treatment of animals with recombinant CTLA-4Ig molecule delays the onset of T1D and other autoimmune diseases $[11,12,32-36]$. However, the function and potential role of sCTLA- 4 have not been well studied. sCTLA- 4 is generated by alternative splicing of CTLA- 4 mRNA, which induces a frame shift by deletion of a transmembrane region of CTLA-4 resulting in a native soluble protein [13]. sCTLA-4 is constitutively expressed on nonstimulated T cells and its expression is downregulated after $\mathrm{T}$ cell activation [14]. The soluble form of surface proteins is believed, in most cases, to play an inhibitory role due to competition for ligands with their surface counterparts. The finding that the sCTLA- 4 expression level remains at sustained levels suggests that sCTLA-4 blocks the B7-mCTLA-4 interaction, thereby enhancing Tcell activation and autoreactivity by inhibiting the induction of anergy $[37,38]$. Alternatively, sustained sCTLA-4 


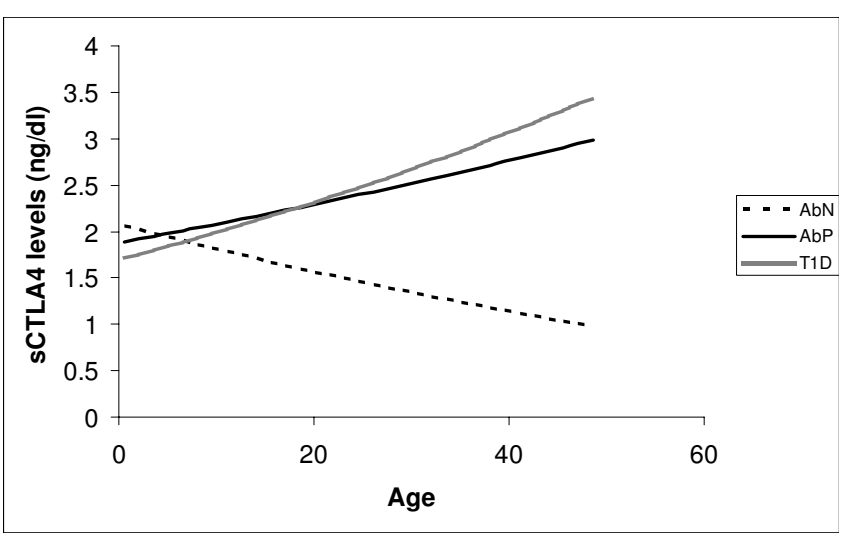

Figure I

Relationship of sCTLA-4 with age and phenotypic groups. The lines shown are the estimated line based on the mixed linear model.

levels may play a protective role via inhibition of the $\mathrm{B} 7$ CD28 interactions. Therefore, the role of sCTLA-4 in autoimmunity may depend on the relative binding affinity of sCTLA-4 to B7.1 and B7.2. This question was indirectly addressed in several autoimmune diseases by comparing the sCTLA-4 levels in the serum of patients and controls. Elevated sCTLA-4 has been reported in organ specific autoimmune thyroid disease [26], systemic lupus erythematosus [27] and myasthenia gravis [28]. These observations suggest that sCTLA-4 may contribute to the development of autoimmune diseases, probably through inhibiting the B7-mCTLA-4 interaction and down-regulation of $\mathrm{T}$ cell activation.

We are unaware of any study that has examined sCTLA-4 levels in the serum of T1D patients. A recent study by Ueda et al. [25], suggested that a SNP (CT60-A/G) in the 3 ' UTR of the CTLA-4 gene may determine the efficiency of the splicing and production of SCTLA- 4 mRNA. Based on a small number of subjects, the susceptible $\mathrm{G}$ allele was suggested to produce lower amounts of sCTLA-4 mRNA. Based on these observations, the authors concluded that sCTLA-4 expression is the functional basis for the observed genetic association between T1D and the CTLA4 gene. If this conclusion were correct, T1D patients would be expected to have lower serum CTLA-4 levels. Our results found no evidence to indicate that sCTLA-4 levels are decreased in patients compared to controls. In contrast, our data suggested that the serum sCTLA-4 levels were slightly higher in T1D patients. Our results also indicated that the increased sCTLA-4 levels in T1D patients were not due to the hyperglycemic conditions because the autoantibody positive subjects also had increased serum sCTLA-4 levels. We also directly tested the correlation between sCTLA-4 levels and the CT-60 SNP in all three phenotypic groups (AbN, AbP and T1D) and found no significant correlation in any of these groups. The discrepancies between our study and the previous report [25] may be explained by a number of factors. First, mRNA was studied in the previous report, while serum protein was analyzed in this study. As the biological function of sCTLA-4 is carried out at the protein level, our data is more applicable to the role of sCTLA- 4 in T1D pathogenesis. Second, the sample size in the previous report [25] was extremely small and random variation is quite likely. Although the sample size in our study is not very large, it is several times larger than the previous report and is sufficiently powered to detect large differences. As there is no indication of a correlation between SCTLA-4 levels and the CT-60 genotype, it is unlikely that the C/T-60 SNP plays a major role in controlling the expression of sCTLA-4.

\section{Conclusion}

Consistent with the observations in other autoimmune diseases in humans as well as data in the NOD mice, our data suggest that SCTLA- 4 is potentially a risk factor for the development of T1D. Our data also raises a serious doubt about the conclusion that the expression of sCTLA-4 is controlled by the CT60 SNP in the 3' end of the CTLA-4 gene. Therefore, the functional basis for the genetic association between CTLA- 4 and autoimmune diseases as well as the etiological mutation in the CTLA- 4 region should be re-considered.

\section{Competing interests}

The author(s) declare that they have no competing interests.

\section{Authors' contributions}

SP and JXS designed the studies, helped with the interpretation and the writing of the manuscript. SP, CC and WZ were primarily involved in carrying out the clinical assessments and the acquisition of data. RP performed the statistical analyses and was involved in preparing the manuscript. AM and DS were responsible for collecting clinical samples and patient evaluation. DH and YH were involved in sample and data collection.

\section{Acknowledgements}

This work was supported by grants from the National Institute of Child Health and Development (2ROIHD37800 and IR2 IHD050 I 96) to JXS. SP was supported by a JDRF postdoctoral fellowship (JDRF \#3-2004-195).

\section{References}

I. Lenschow DJ, Walunas TL, Bluestone JA: CD28/B7 system of T cell costimulation. Annu Rev Immunol 1996, I4:233-258.

2. Linsley PS, Brady W, Urnes M, Grosmaire LS, Damle NK, Ledbetter JA: CTLA-4 is a second receptor for the $B$ cell activation antigen B7. J Exp Med 199I, 174:56I-569.

3. Linsley PS, Brady W, Grosmaire L, Aruffo A, Damle NK, Ledbetter JA: Binding of the $B$ cell activation antigen B7 to CD28 costimulates $T$ cell proliferation and interleukin 2 mRNA accumulation. J Exp Med 199I, 173:721-730. 
4. Brunet JF, Denizot F, Luciani MF, Roux-Dosseto M, Suzan M, Mattei MG, Golstein P: A new member of the immunoglobulin superfamily - CTLA-4. Nature 1987, 328:267-270.

5. Walunas TL, Bakker CY, Bluestone JA: CTLA-4 ligation blocks CD28-dependent $\mathbf{T}$ cell activation. I Exp Med 1996, I 83:254I-2550.

6. Krummel MF, Allison JP: CD28 and CTLA-4 have opposing effects on the response of $T$ cells to stimulation. J Exp Med 1995, 182:459-465.

7. Leach DR, Krummel MF, Allison JP: Enhancement of antitumor immunity by CTLA-4 blockade. Science 1996, 271:1734-1736.

8. Tivol EA, Borriello F, Schweitzer AN, Lynch WP, Bluestone JA Sharpe AH: Loss of CTLA-4 leads to massive lymphoproliferation and fatal multiorgan tissue destruction, revealing a critical negative regulatory role of CTLA-4. Immunity 1995, 3:54I-547.

9. Karandikar NJ, Vanderlugt CL, Walunas TL, Miller SD, Bluestone JA CTLA-4: a negative regulator of autoimmune disease. J Exp Med 1996, 184:783-788.

10. Waterhouse P, Penninger JM, Timms E, Wakeham A, Shahinian A, Lee KP, Thompson CB, Griesser H, Mak TW: Lymphoproliferative disorders with early lethality in mice deficient in Ctla-4. Science 1995, 270:985-988.

II. Luhder F, Hoglund P, Allison JP, Benoist C, Mathis D: Cytotoxic T lymphocyte-associated antigen 4 (CTLA-4) regulates the unfolding of autoimmune diabetes. I Exp Med 1998 187:427-432.

12. Luhder F, Chambers C, Allison JP, Benoist C, Mathis D: Pinpointing when $T$ cell costimulatory receptor CTLA-4 must be engaged to dampen diabetogenic T cells. Proc Natl Acad Sci USA 2000, 97: 12204-12209.

13. Magistrelli G, Jeannin P, Herbault N, Benoit DC, Gauchat JF, Bonnefoy JY, Delneste Y: A soluble form of CTLA-4 generated by alternative splicing is expressed by nonstimulated human $\mathrm{T}$ cells. Eur J Immunol 1999, 29:3596-3602.

14. Oaks MK, Hallett KM, Penwell RT, Stauber EC, Warren SJ, Tector AJ: A native soluble form of CTLA-4. Cell Immunol 2000 20I: I44-I53.

15. Marron MP, Raffel LJ, Garchon HJ, Jacob CO, Serrano-Rios M, Martinez Larrad MT, Teng WP, Park Y, Zhang ZX, Goldstein DR, Tao YW, Beaurain G, Bach JF, Huang HS, Luo DF, Zeidler A, Rotter JI, Yang MC, Modilevsky T, Maclaren NK, She JX: Insulin-dependent diabetes mellitus (IDDM) is associated with CTLA4 polymorphisms in multiple ethnic groups. Hum Mol Genet 1997, 6:1275-1282.

16. Marron MP, Zeidler A, Raffel LJ, Eckenrode SE, Yang JJ, Hopkins DI, Garchon HJ, Jacob CO, Serrano-Rios M, Martinez Larrad MT, Park Y Bach JF, Rotter Jl, Yang MC, She JX: Genetic and physical mapping of a type I diabetes susceptibility gene (IDDMI2) to a 100-kb phagemid artificial chromosome clone containing D2S72-CTLA4-D2SI 05 on chromosome 2q33. Diabetes 2000, 49:492-499.

17. Nistico L, Buzzetti R, Pritchard LE, Van der AB, Giovannini C, Bosi E, Larrad MT, Rios MS, Chow CC, Cockram CS, Jacobs K, Mijovic C Bain SC, Barnett AH, Vandewalle CL, Schuit F, Gorus FK, Tosi R, Pozzilli $P$, Todd JA: The CTLA-4 gene region of chromosome $2 q 33$ is linked to, and associated with, type I diabetes. Belgian Diabetes Registry. Hum Mol Genet 1996, 5: 1075-1080

18. Donner H, Rau H, Walfish PG, Braun J, Siegmund T, Finke R, Herwis J, Usadel KH, Badenhoop K: CTLA4 alanine- 17 confers genetic susceptibility to Graves' disease and to type I diabetes mellitus. J Clin Endocrinol Metab 1997, 82: 143-I 46.

19. Van der Auwera BJ, Vandewalle CL, Schuit FC, Winnock F, De Leeuw IH, Van Imschoot S, Lamberigts G, Gorus FK: CTLA-4 gene polymorphism confers susceptibility to insulin-dependent diabetes mellitus (IDDM) independently from age and from other genetic or immune disease markers. The Belgian Diabetes Registry. Clin Exp Immunol 1997, I 1 0:98-103.

20. Yanagawa $T$, Hidaka $Y$, Guimaraes $V$, Soliman M, DeGroot LJ: CTLA4 gene polymorphism associated with Graves' disease in a Caucasian population. J Clin Endocrinol Metab 1995, 80:4I-45.

21. Kemp EH, Ajjan RA, Husebye ES, Peterson P, Uibo R, Imrie H, Pearce $\mathrm{SH}$, Watson PF, Weetman AP: A cytotoxic T lymphocyte antigen-4 (CTLA-4) gene polymorphism is associated with autoimmune Addison's disease in English patients. Clin Endocrinol 1998, 49:609-6I3.
22. Kotsa K, Watson PF, Weetman AP: A CTLA-4 gene polymorphism is associated with both Graves disease and autoimmune hypothyroidism. Clin Endocrinol 1997, 46:55I-554.

23. Huang D, Giscombe R, Zhou Y, Lefvert AK: Polymorphisms in CTLA-4 but not tumor necrosis factor-alpha or interleukin Ibeta genes are associated with Wegener's granulomatosis. J Rheumatol 2000, 27:397-40I.

24. Huang D, Liu L, Noren K, Xia SQ, Trifunovic J, Pirskanen R, Lefvert AK: Genetic association of Ctla-4 to myasthenia gravis with thymoma. J Neuroimmunol 1998, 88:192-198.

25. Ueda H, Howson JM, Esposito L, Heward J, Snook H, Chamberlain G, Rainbow DB, Hunter KM, Smith AN, Di Genova G, Herr MH, Dahlman I, Payne F, Smyth D, Lowe C, Twells RC, Howlett S, Healy B, Nutland S, Rance HE, Everett V, Smink LJ, Lam AC, Cordell HJ, Walker NM, Bordin C, Hulme J, Motzo C, Cucca F, Hess JF, Metzker ML, Rogers J, Gregory S, Allahabadia A, Nithiyananthan R, Tuomilehto-Wolf E, Tuomilehto J, Bingley P, Gillespie KM, Undlien DE, Ronningen KS, Guja C, lonescu-Tirgoviste C, Savage DA, Maxwell AP, Carson DJ, Patterson CC, Franklyn JA, Clayton DG, Peterson LB, Wicker LS, Todd JA, Gough SC: Association of the T-cell regulatory gene CTLA4 with susceptibility to autoimmune disease. Nature 2003, 423:506-5II.

26. Oaks MK, Hallett KM: Cutting edge: a soluble form of CTLA-4 in patients with autoimmune thyroid disease. J Immunol 2000 , 164:50I5-5018.

27. Liu MF, Wang CR, Chen PC, Fung LL: Increased expression of soluble cytotoxic T-lymphocyte-associated antigen-4 molecule in patients with systemic lupus erythematosus. Scand J Immunol 2003, 57:568-572

28. Wang XB, Kakoulidou M, Giscombe R, Qiu Q, Huang D, Pirskanen R, Lefvert AK: Abnormal expression of CTLA-4 by $T$ cells from patients with myasthenia gravis: effect of an AT-rich gene sequence. J Neuroimmunol 2002, 130:224-232.

29. She JX, Bui MM, Tian XH, Muir A, Wakeland EK, Zorovich B, Zhans LP, Liu MC, Thomson G, Maclaren NK: Additive susceptibility to insulin-dependent diabetes conferred by HLA-DQBI and insulin genes. Autoimmunity 1994, 18:195-203.

30. Wasserfall C, Atkinson M, Jodoin E, Schatz D, She JX, Henderson LO, Ellis T: Glutamic acid decarboxylase and IA-2 autoantibodies in type I diabetes: comparing sample substrates for autoantibody determinations. Pediatr Diabetes 2000, I:10-16.

31. Bingley PJ, Bonifacio E, Williams AJ, Genovese S, Bottazzo GF, Gale EA: Prediction of IDDM in the general population: strategies based on combinations of autoantibody markers. Diabetes 1997, 46: $170 \mid-1710$

32. Mclntosh KR, Linsley PS, Bacha PA, Drachman DB: Immunotherapy of experimental autoimmune myasthenia gravis: selective effects of CTLA4Ig and synergistic combination with an IL2-diphtheria toxin fusion protein. J Neuroimmunol 1998, 87:136-146.

33. Davidson A, Wang X, Mihara M, Ramanujam M, Huang W, Schiffer L, Sinha J: Co-stimulatory blockade in the treatment of murine systemic lupus erythematosus (SLE). Ann N Y Acad Sci 2003, 987: $188-98$

34. Verwaerde C, Naud MC, Delanoye A, Wood M, Thillaye-Goldenberg $B$, Auriault C, de Kozak Y: Ocular transfer of retinal glial cells transduced ex vivo with adenovirus expressing viral IL- 10 or CTLA4-Ig inhibits experimental autoimmune uveoretinitis. Gene Ther 2003, 10: 1970-1981.

35. Kremer JM, Westhovens R, Leon M, Di Giorgio E, Alten R, Steinfeld $S$, Russell A, Dougados M, Emery P, Nuamah IF, Williams GR, Becker JC, Hagerty DT, Moreland LW: Treatment of rheumatoid arthritis by selective inhibition of T-cell activation with fusion protein CTLA4Ig. N Engl J Med 2003, 349:1907-1915.

36. Najafian N, Sayegh MH: CTLA4-Ig: a novel immunosuppressive agent. Expert Opin Investig Drugs 2000, 9:2 147-2 I57. not cited in text

37. Carreno BM, Bennett F, Chau TA, Ling V, Luxenberg D, Jussif J, Baroja ML, Madrenas J: CTLA-4 (CDI52) can inhibit T cell activation by two different mechanisms depending on its level of cell surface expression. J Immunol 2000, 165:| 352-1356.

38. Pandiyan P, Gartner D, Soezeri O, Radbruch A, Schulze-Osthoff $K$, Brunner-Weinzierl MC: CDI52 (CTLA-4) determines the unequal resistance of ThI and Th2 cells against activationinduced cell Death by a mechanism requiring PI3 kinase. Exp Med 2004, 199:83।-842. 